ROCZNIKI KULTUROZNAWCZE

Tom/Vol. XI, numer/number $3-2020$

DOI: http://dx.doi.org/10.18290/rkult20113-5

\author{
PAUL RICHARD BLUM
}

\title{
EPIDEMIC AND THE INDIVIDUAL: RENAISSANCE UNDERSTANDINGS OF THE PLAGUE IN VIEW OF MODERN EXPERIENCES
}

Epidemics, the pestilence or the plague, are illnesses that affect a great number of people simultaneously and over a long time. They are distinct from other diseases for that reason that they spread out and, thus, involve all who are affected and also every related person. For instance: high blood pressure, cancer, or diabetes are widely occurring medical problems, and yet, in our time we would call them epidemics only in a metaphorical sense; for many individuals are affected, but every patient is ill in individual terms and conditions. The plague, on the contrary, affects all, even the healthy ones, and therefore requires both a different kind of treatment and special communal consideration. Several years ago, the mayor of a metropolitan area decreed reducing salt and sugar in drinks for public consumption; the intent was to fight blood pressure and overweight disorders among the citizens. But the opponents decried this action as "nanny state" policy that deprives the citizens of their right to select their food. This shows, that health is a matter of individual choices, even if these choices are made in masses and fatally.

One example regarding the general and the personal outlook of diseases in our times is a linguistic detail. When the news reports a person has taken ill or died, we do not hear that person "suffered from cancer" (or diabetes or any other illness) or died of it or battled with it; rather the formula is: "suffered from his/her cancer" (etc.). The suffering is personal and owned by the suffering individual (something Stoicism would sternly refute), whereas medically speaking that individual was affected by an external attack and a disease, which would not even be treatable, if it were just individual rather

Paul Richard Blum, Ph.D. - Loyola University Maryland, Baltimore; e-mail: PRBlum@ loyola.edu. ORCID: https://orcid.org/0000-0003-4181-2673. 
than generic. In speaking in this sort of pattern, the community denies or veils the fact that all of those medical problems are rampant and, frequently enough, outcomes of the way of life in modern Western society that prides itself of being individualistic and global at the same time. In this perspective a periodical published recently, in Spring 2020, contains some responses to the crisis of the Corona Virus (Covid-19) by academic philosophers in Germany, and the result is symptomatic: the common denominator of the responses was Angst, i.e., the anxiety felt by individuals across the societal strata and public institutions, a psychological response of individuals to the general threat. ${ }^{1}$ Although this was explained with reference to existentialist philosophies, precisely because existentialism frames the objective as rooted in the subject, the responses failed to understand that also this present-day plague is in and of itself not a personal human condition but a global and objective biological/medical condition that affects human beings exactly because it is external rather than something ghostly we have to live with. While taking recourse to the existentialist Angst, the backdoor opens to occultist threats. Evidence for this is an observation by Carlo Ginzburg who, as we know, is well familiar with the behavior of ordinary people. He detected elements of religious, Biblical, language in the formula "herd immunity," as it is currently used in describing strategies to overcome the Corona pandemic, which is an obscure outreach to transcendent healing (the Savior caring for His herd) that evokes the perception of the suffering of the individual person as a sacrifice for the salvation of the masses. In present sanitary politics this amounts to "herd democracy" which is just another word for totalitarianism. ${ }^{2}$

This particular trait of epidemies, namely, their relevance for the community at large and their universal outlook, was known to the older theorists of medicine, and it appears to return in our age when the global interconnectedness of the political, physical, and mental order and disorder reenter the stage. What is interesting, however, is the difference in approach in our times and in the Renaissance. In the past, the challenge of the plague as a universal threat was addressed in universalizing forms of reasoning.

\footnotetext{
${ }^{1}$ Bärbel Frischmann, "Das Virus und die Angst," Information Philosophie, no. 2 (2020): 8-15; "Covid-19 und die PhilosophInnen. Eine Übersicht über die mediale Präsenz der Philosophie," Information Philosophie, no. 2 (2020): 16-25.

${ }^{2}$ Carlo GinzBurg, "Une démocratie grégaire?," En attendant Nadeau (blog), July 11, 2020, https://www.en-attendant-nadeau.fr/2020/07/12/democratie-gregaire-ginzburg/.
} 
Pestilence is a feverish infection, infested with dire sicknesses that come with it; it is contagious and fatal for most or at least many humans at one and the same time. ${ }^{3}$

This is how Georg Agricola (1494-1555), best known for his works on mining, but also trained as a medical doctor, defines the plague in his treatise On the Plague in 1554. This definition still holds true for what we call epidemic or pandemic, especially regarding the contagiousness and the spread. As a scientist, Agricola considers the causes and gently dismisses the theological and the astrological origin. He excuses himself that, as a scientist, he may not contradict the explanation according to which God uses the plague as a punishment, nor does he flatly deny the influence of astral constellation. Instead of taking recourse to abstract notions, as the philosopher does (including the author of this paper), Agricola investigates the "evident causes," which consist in the fact that "the plague comes most frequently from heavy and pestilential air, less frequently from a long lasting intemperance of the air, and more rarely from food and drink that make body fluids prone to decay and fever." The most common cause of plague, then, is air that has been made pestilential through festering and decaying corpses and their exhalations. ${ }^{4}$ From a theoretical point of view, Agricola is reducing the overarching causality of divine intervention and celestial influx to the state of the air, which, on the other hand, is modified by death and rottenness of the organic life. He is claiming to argue empirically, and yet he cannot forego a systematic link between the surrounding element of air and the particular state of corrosion in that which is surrounded by air. The philosopher rises to the level of the metaphysically universal, the naturalist invokes overarching realities (including divine intervention and astral powers), but the empirical doctor establishes the interaction between the concrete life and death and the physical surrounding or environment to the extent that both the environment and the bodies are affecting each other mutually.

Renaissance scientists and philosophers were not at all working in a merely theoretical realm. Marsilio Ficino's treatise is intended to be an advice for his contemporaries, and the same is true for the books by Girolamo Fracastoro and Jean Fernel, which I will briefly introduce. As much as the current Corona crisis is for us, the plague and epidemies were a daily

\footnotetext{
${ }^{3}$ Georg Agricola, De peste libri tres (Basel: Froben, 1554), 10: "pestis est lues febrilis, diris malis, quae simul cum ea incident, infesta, contagiosa, plurimis hominibus, aut certe multis uno eodemque tempore perniciosa." - For the purpose of this paper I will refrain from identifying and comparing sources.

${ }^{4}$ Agricola, De peste libri tres, 10-11.
} 
experience and danger for them. The bubonic plague kept persistently killing people ever since the famous plague of 1348 that remains associated with Giovanni Boccaccio's Decameron. ${ }^{5}$ What we should find out in the Renaissance authors are hints as to where to search for remedies, and not just treatments for individual sick persons but for the plague as a universal phenomenon that realizes itself in medical cases.

\section{MARSILIO FICINO}

Marsilio Ficino (1433-1499), known as the most important Platonist of the Renaissance, wrote in 1481 an Advice against the Plague responding to a recent outbreak and leaning on the practical experience of his father, Diotefeci, a practicing physician. ${ }^{6} \mathrm{He}$ defines the plague as "a poisonous vapor born in the air, inimical of the vital spirit" (ch. 1), and he explains the poisonousness by contrasting it with theriac. The vapor of the plague is inimical not because of its single properties like warm/cold and dry/humid (the basic properties of the four elements) but due to the specific proportion that is opposite the properties of the vital spirit in a human body. This is not present-day science, so a few explanations are in order. The vital spirit is that condition that keeps an animate body alive and is both spiritual and corporeal. A residue of that knowledge is present in the modern meaning of spirits for alcohol. The key theory, here, is that the pestilential vapor is of a composition that is opposed to the life of the body. In contrast, theriac is a medicine that works because it is proportionate to the vital spirit. Theriac, a medical concoction based on the poison of vipers (which is also entailed in its name derived from Greek therion), has been known from antiquity. ${ }^{7}$ It is

\footnotetext{
${ }^{5}$ Ada Palmer, "Black Death, COVID, and Why We Keep Telling the Myth of a Renaissance Golden Age and Bad Middle Ages," Ex Urbe. History, Philosophy, Books, Food \& Fandom, accessed July 14, 2020, https://www.exurbe.com/black-death-covid-and-why-we-keep-telling-themyth-of-a-renaissance-golden-age-and-bad-middle-ages/. On epidemics and medicine at the time cf. Sabine Herrmann, Tomaso Rangone: Arzt, Astrologe und Mäzen im Italien der Renaissance (Göttingen: Vandenhoeck \& Ruprecht, 2017); for a list of occurrences of the plague see George Childs KoHn, Encyclopedia of Plague and Pestilence, $3^{\text {rd }}$ ed. (New York: Facts On File, 2008), $475 \mathrm{f}$.

${ }^{6}$ Marsilio Ficino, Consilio contro la pestilenzia, ed. Enrico Musacchio (Bologna: Cappelli, 1983) (the introduction by Giampaolo Moraglia scetches the history of medical advice regarding the plague); Teodoro Katinis, Medicina e filosofia in Marsilio Ficino: Il Consilio contro la pestilenza (Roma: Edizioni di Storia e Letteratura, 2007), also contains the text; for practical reasons I cite the former edition. For an interpretation in English see Teodoro Katinis, "A Humanist Confronts the Plague: Ficino's Consilio Contro La Pestilentia," Modern Language Notes 125, no. 1 (2010): 72-83.

${ }^{7}$ An informative but dismissive explanation of theriac is Donald BEECHER, "Ficino, Theriaca and
} 
the paradigmatic antidote: healing poison with poison. In his other medical work, the more theoretical De vita, Ficino explains the effectiveness of theriac as follows: this medicine does not remove nor alter the poison, rather, it strengthens the tender and changeable vital spirit immediately through an appropriate proportion to the effect that the vital spirit can become an agent itself, with the theriac as a means, and thus overcome, modify, or fend off the poison from the vital parts. This proportionate power comes from Jove and the Sun (Jupiter and Phoebus). Therefore, Ficino continues, theriac is effective thanks to the celestial power; there is a different celestial power in the herbs and spices, and there are elemental powers, which all work together to fortify the vital spirit against the disease. This cooperation of celestial power acquired purposefully with naturally stored celestial properties and elements is what renders the medication effective. ${ }^{8}$

That sets the scene for a practical approach to the illness in the Advice: a living organism is deranged by an external unfitting air and may be cured by a medication that derives its powers from a particular poison. Ficino clarifies that the poisonousness of the air is generic, but it does not affect every person indistinctively but only those organisms that are already out of order for having certain putrefying or boiling humors. It is the condition of the body that invites the air to become infectious. We see a clear tension between the external world and the ailing body and an interaction of fighting back against the infection by strengthening itself.

When Ficino addresses the origin of the plague (ch. 2) he explains that all pestilences grow out of the air from the nocuous constellations, specifically Mars and Saturn, which then impact people and places with unlucky astrological positions. ${ }^{9}$ In some epidemics the poison arises from winds and evil vapors, lakes, morasses, and earthquakes. Again, not every person is affected

the Stars," in Marsilio Ficino: His Theology, His Philosophy, His Legacy, ed. Michael J. B. Allen, Valery Rees, and Martin Davies (Leiden: Brill, 2001), 243-56.

${ }^{8}$ Marsilio Ficino, Three Books on Life, ed. Carol V. Kaske and John R. Clark (Binghamton, N.Y.: Medieval \& Renaissance Texts \& Studies, 1989), bk. III 12, p. 302.

${ }^{9}$ On Ficino's medical theories in connection with astrology cf. Susanne BeIwEIs, "Saturn und Talisman: Die heterogenen Begriffe der Magie am Beispiel von Marsilio Ficinos 'De vita libri tres", (Phil. Diss., Wien, 2015); Susanne K. BeIweIs, “ 'Naturam Ars Imitatur': Magical Images within Marsilio Ficino's De Vita Libri Tres," Verbum - Analecta Neolatina 19, no. 1-2 (2018): 155-80, $\mathrm{http}: / /$ www.verbum-analectaneolatina.hu/en_issue.php?issue=XIX/2018/1-2. On Renaissance astromedicine Wolf-Dieter Müller-JaHncke, Astrologisch-magische Theorie und Praxis in der Heilkunde der frühen Neuzeit, Sudhoffs Archiv, Beiheft 25 (Stuttgart: Steiner, 1985); Hiro HiraI, "The New Astral Medicine," in A Companion to Astrology in the Renaissance, ed. Brendan Dooley (Leiden: Brill, 2014), 267-86. 
but only those that have a disposition which is key to the effect. Generally speaking, he explains, the medical rule holds: When the matter is so disposed the agent works effectively, even if it is weak; and vice versa, a highly potent agent is effective on the matter, even if that seems not disposed for it. The medical cures that follow regard conduct of life regarding food and drink (ch. 5); then follows medication, especially theriac but also pills according to precise recipes, liquid medicine, and bloodletting (ch. 6); then follow further prescriptions and cures that pertain to the practical expertise of physicians mostly geared at strengthening and restoring the patient. The book closes with the advice to keep cups, plates, and bedsheets clean, to be cautious with cattle, horses, and other animals, and with a prayer that God may reveal remedies. Are we surprised that these cautionary measures are valid even in the pandemic that started in the early $20^{\text {th }}$ century?

Those details are important for the history of medicine as a discipline and a practice; philosophically, this approach to the epidemy shows a form of thought that is certainly typically humanistic. Ficino addresses the endangerment from the outside, identifies its natural location in the totality of the environment, and then plays it off against the human individual. The patient is not helplessly suffering but has to search the remedy in the body and behavior as it is personally owned. The pest can only affect the body if it is weak or at least weaker than the external infection. Therefore, protection and cure depend on both strengthening the body and weakening and reigning in of the inimical environment. The physician and the patient consider the place of the human being in the world, they observe and appraise the external conditions, and rearrange that constellation as best they can.

\section{GIROLAMO FRACASTORO}

Girolamo Fracastoro (1477-1553) responded to a very new and threatening pestilence, namely the Syphilis. He created, indeed, the name for this disease in his poem Syphilis sive de morbo gallico. The poem in three books with 1346 hexameters offers medical and historical information combined with mythological traits. It opens with the consideration that this new affliction is actually not new but only resurgent from antiquity. The disease sure appears to have been brought from the West by Spaniards so that international trade (commercium) is supposed to cause it. However, relying on observation, Fracastoro points to the enormous speed of the circulation of 
the disease all over Europe. Hence follows the task to investigate the "order" (ordo) in which the illness has spread. This entails that the syphilis has been latent for a long time in history and is yet the same. ${ }^{10}$ According to astromedicine of the time, the illness spreads through the air under the constellation of the stars, which makes it understandable that the air can also carry new diseases and new contagions for a long stretch of times. ${ }^{11}$ On the whole, this is a historicizing view on the pestilence, based on the observation of occurrences. It is surprising, then, that the poet turns to the suffering of a single case: he knew a handsome, athletic young man who was overly confident; the ruin seized him (perhaps cursed by a girl he had rejected) with all kinds of deformities and suffering. ${ }^{12}$ From there follow considerations about the reasons that made Italy subject to the plague, including discord that had led to the French invasion of 1508-1511.

We see Fracastoro cast the plot in medical, empirical, ethical, and political terms. In the second book, he approaches therapy (avoiding contact, certain airs, diet) and narrates the discovery of quicksilver (mercury) in mythological key. In all this he keeps reminding the readers that he is speaking as a physician and advisor, thus relativizing the poetic appearance in favor of practice.

The third book offers yet another remedy, this time one that comes from the same place as the newly discovered plague, the new world. Guaiacum, a wood, was known to provide a therapeutic potion, and the poet explains the procedures, including the astro-medical conditions. Then follows a narration of the voyage of Columbus. The arrival of the explorers turns out to be an intrusion of religious proportions that deserve the curse with a new affliction pronounced by one bird of a swarm that had been frivolously attacked with guns by the Europeans. ${ }^{13}$ Here we also learn the mythic origin of the pestilence as a vengeance of the gods and especially Apollo. A shepherd named Syphilus had decided to honor only the king rather than the gods and enticed his fellow rustics to do the same. For inventing rites and raising altars to the

${ }^{10}$ Girolamo Fracastoro, "Syphilis sive de morbo gallico," in Latin poetry, trans. James Gardner (Cambridge, MA: The I Tatti Renaissance Library, Harvard University Press, 2013), bk. I, 32-131. On Fracastoro see the comprehensive volume Alessandro Pastore and Enrico Peruzzi (eds.), Girolamo Fracastoro fra medicina, filosofia e scienze della natura: Atti del convegno internazionale di studi in occasione del 450. anniversario della morte, Verona-Padova 9-11 ottobre 2003 (Firenze: Olschki, 2006).

${ }^{11}$ Fracastoro, "Syphilis," bk. I, 83-85; 182-185. The constellations that facilitated the spread are discussed lines 197-260.

${ }^{12}$ Fracastoro, "Syphilis," bk. I, 382-420.

${ }^{13}$ Fracastoro, "Syphilis," bk. III, 174-193. 
king he was the first to be afflicted by what then was named Syphilis. ${ }^{14}$ Whenever people are faced with suffering and especially when its cause and scope is hard to fathom, punishment by God is one of the possible assumptions. Fracastoro's poetical framing offers a rationalizable explanation: humans as active beings transgress boundaries in various ways, for instance, as they intrude a foreign civilization, violate the integrity of nature, and commit sacrileges against the divine order. That, we can assume, was true not only at this particular point in history, but is one of the weaknesses of human culture.

This consideration also helps interpreting why Fracastoro is rather silent about the fact that Syphilis is a venereal disease. In book II of the poem he mentions among the cautionary measures to "distrust" the bed and slumber because these are beguiling and foster the vice; rather, one should seek pleasure in songs and dances of boys and girls. However, avoid Venus and unmanly coitus, he warns, for Venus and tender girls hate the contact (contagem). ${ }^{15}$ Evidently, sexual activity is just one detail of human behavior, so that, even if the illness is transmitted this way, it is still to be considered in the context of the overall attitude towards fellow humans and the care for personal health. In his later scientific book On Contagions, Fracastoro confirms the message of the poem Syphilis. Here he says clearly that bodily contact alone is not infectious but only when bodies are heated up as happens during coitus; he also observes that breastfed babies can be infected. Since the disease can spread without contact, and since pestilences come and go over long periods, it has to be classified as one of the plagues that depend on many factors, including astronomical situations. ${ }^{16}$

If there appears to be a tension between the universal occurrence of the disease - geographically and historically - and the narrative of an origin with a name and a place and a time, the message may be that all people are

\footnotetext{
${ }^{14}$ Fracastoro, "Syphilis," bk. III, 310-332.

${ }^{15}$ Fracastoro, "Syphilis," bk. II, 105-115: "Tu lector ne crede, gravi ne crede sopori, his alitur vitium ... Parce tamen Veneri, mollesque ante omnia vita concubitus ..." It is possible that molles concubitus refers to pederasty (cf. 1 Cor 6:10), abhorred by Venus and young girls — but that is not important here. On sexual transmission of syphilis in this and other passages see Ruth MonREAL, "Eppur lo dice! Come si trasmette la sifilide nel poema didattico di Girolamo Fracastoro," Studi Umanistici Piceni 23 (2003): 179-89.

${ }^{16}$ Hironymus Fracastorius, "De contagionibus et contagiosis morbis et eorum curatione," in Opera omnia (Venetiis: Iunta, 1584), 77r-110v; bk. II, cap. 2, p. 91r and 92r. Book III, chapter 10 explains therapies. On the development of Fracastoro's theories see Virginia Iommi EcheverRíA, "Girolamo Fracastoro y la invención de la sífilis," História, Ciências, Saúde-Manguinhos 17, no. 4 (December 2010): 877-84. DOI: https://doi.org/10.1590/S0104-59702010000400002.
} 
naturally inclined to blame a culprit. Fracastoro expresses this when he shifts the name from "French Disease" (morbus Gallicus) to Syphilis. Instead of accusing the above-mentioned French invasion (or, for that matter, the migrants to and from the New World) he shifts the culpability to a mythical character, Syphilus, who embodies the individual perpetrator as a representative of humankind. The question "Who done it?" and the accusation that follows from it is ingrained in human nature, so that the only remedy is to care for the individual through research that is based on scientific method. In the pandemic of the year 2020 it has become obvious that blaming one particular source is nothing but scapegoating without noticeable results, while the universal crisis can only be contained through responsible behavior of each and every person. The awareness of such responsibility, however, is dependent on the insight in into the universality of the individual hardship.

\section{JEAN FERNEL}

Jean Fernel (1497-1558), a French physician, supported the theory that the syphilis had its origin in Europe from Naples and was certainly introduced in the wake of the exploration of the New World. He rejected the theory that constellations caused the dissemination and extension of the illness all over Europe, rather he confirmed the observation that sexual intercourse, breastfeeding and other immediate bodily contacts were infectious. However, he also tried to dispel various rumors by stating that the origin of an epidemic is less important than information about the mechanisms and effects of the illness, from whence to derive appropriate therapies. ${ }^{17}$ One remark in this context strikes as relevant also in present-day experience, namely, the expectation that plagues come and disappear in a short time. That is not the reality we need to face, he says. Rather, unless God extinguishes the disease or contains human libido, it will remain a "companion"

\footnotetext{
${ }^{17}$ Jean Fernel, On the Hidden Causes of Things, ed. John Henry and John M. Forrester, trans. John M. Forrester [De abditis rerum causis, Lat.-Engl.] (Leiden: Brill, 2005), bk. II, chap. 14, p. 614. On Fernel's theory of medicine see "Jean Fernel and His Christian Platonic Interpretation of Galen" in Hiro HiRAI, Medical Humanism and Natural Philosophy: Renaissance Debates on Matter, Life and the Soul (Leiden: Brill, 2011), chap. 2. And compared with Ficino and Fracastoro: Hiro HIRAI, "Ficin, Fernel et Fracastor autour du concept de semence: Aspects platoniciens de seminaria," in Girolamo Fracastoro fra medicina, filosofia e scienze della natura: Atti del convegno internazionale di studi in occasione del 450. anniversario della morte, Verona-Padova 9-11 ottobre 2003, ed. Alessandro Pastore and Enrico Peruzzi (Firenze: Olschki, 2006), 245-60.
} 
to humanity and "immortal."18 (Talking of sexual desire and a deadly disease, this is certainly said tongue-in-cheek.) On the other hand, people tend to rush to all sorts of unapproved medications, for instance mercury and potions. It is not the illness but the anxiety that makes people do so, not knowing that this remedy only cures the symptoms and cures can have grave side effects like shooting with canons. ${ }^{19}$ What needs to be done is knowing the essence and nature of the disease, as stated before. Fernel was not an existentialist as the philosophers mentioned at the beginning of this essay.

Lues is only one of many illnesses studied in Fernel's book On the Hidden Causes of Things. The major principle and first task of medicine is to know the physiology of the human body, its parts and composition, and the operations; this is only done by conceptualizing observations regardless whether one ascribes the causes to their foundation and temperaments or to divine origin. ${ }^{20}$ That has a skeptic ring, and an empirical one; or we might call it pragmatic. This also helps learning from his discussion of the plague.

Referring to the standard explanation that pestilences are airborne, he clarifies that air as such is clean, but once polluted it scatters the illness like seeds. Turned infectious, the air becomes endemic, as he terms it, and epidemic while spreading out universally. Pollutions from heaven then produce pestilences. ${ }^{21}$ Not as a scientific explanation but as a feature of human experience, Fernel suggests that these huge developments in nature cannot be reduced to weather phenomena and therefore plausibly lead to assume a highest general cause from the sublime. ${ }^{22}$ Evidently, the pestilence cannot be fully explained with putrefaction. In other words, the causes of pestilences are blind, obscure, and hidden (caeca, obscura et abdita) in being directly opposed to substance and destructive for the entire genus so that they cannot come from elements or their qualities. Hence, every cause of the pestilence is blind and destructive coming from somewhere else, namely from astral constellations. Whoever denies this explanation suffers from serious stupidity; given that stars take care of the salvation and conservation, they can also provide for downfall of a life that is in bad order. ${ }^{23}$

\footnotetext{
${ }^{18}$ Fernel, On the Hidden Causes of Things, 620.

${ }^{19}$ Ibid., 620-22.

${ }^{20}$ Ibid., bk. II, chap. 8, pp. 510-512: "In medicinae physiologia satis quidem mihi esse duco, si humani corporis compositionem ac structuram singularumque partium functiones et usus mente consequar: parum curans, sive illarum causas rerum primordiis et temperament, sive diviniori origini attribuas."

${ }^{21}$ Ibid., bk. II, chap. 12 , pp. 562-564.

${ }^{22}$ Ibid., bk. II, chap. 12, p. 568.

${ }^{23}$ Ibid., bk. II, chap. 12, p. 572.
} 
We may notice in this line of argument that Fernel as a scientist focuses on the phenomena as they are reported and observable; in that sense, he is an empiricist. At the same time he notices two limits of scientific treatment of plagues: human weakness and the deficiency of data. Humans not only have unhealthy conduct of life they also are scared and take recourse to irrational measures. Even the level minded ones may refer to supernatural causation. The sober scientist, on the other hand, has to acknowledge the fact that some explanations escape empirical patterns. Pestilence is blind, that is, it works without an appreciable purpose, and its origin and mechanisms remain obscure. At this point we should remember that lues and plague are only exemplary cases and applications of the main topic of the book, namely, to integrate the study of medicine in a general theory of occult causes: On the Hidden Causes of Things. The entire first book is a philosophical study of the natural world in terms of substance, form, powers, generation, and spirits. In this metaphysical and empirical approach, Fernel re-discusses the existing theory of occult qualities and forces that was standard at his time. Occult qualities had always been shorthand for natural phenomena that escape physical explanation (think of magnetism). Inevitably, they could either point to supernatural interventions by angels or demons or serve as a subterfuge verging on occultism. It was Fernel in this book who refined the theory of occult powers as a methodical delineation of the limits and possibilities of scientific explanation and its desiderata. ${ }^{24}$ Fernel defines occult causes as follows: any admirable performance, the cause of which is hidden, concealed, and occult and cannot be proven or definitely explained needs to be related to the divine. That includes whatever does not come out of the simple properties of things and transcends human understanding. To that he adds: well, if you recognize it to be divine, it is not anymore uncertain or hidden. ${ }^{25} \mathrm{He}$ might have said that with a hint of irony. For, that is precisely the role of this theory of hidden powers, to contain scientific uncertainty with method to the extent that recourse to divine or spiritual intervention loses the taste of spookiness or superstition.

\footnotetext{
${ }^{24}$ The editors of the text appear to ridicule occult qualities disregarding their role as a prelude to empiricism: Fernel, 25. Cf. Paul Richard Buum, "Qualitas occulta," in Historisches Wörterbuch der Philosophie, vol. 7 (Basel: Schwabe, 1989), 1743-47.

${ }^{25}$ Fernel, On the Hidden Causes of Things, bk. II, chap. 8, p. 496.
} 


\section{CONCLUSION}

The plague was not an individual disease, but an epidemic. And yet, it was no different from individual diseases, as throughout Christianity personal diseases were always seen embedded in the overall picture of the nature and activity of God. If up to the $17^{\text {th }}$ century the influences of certain planets and constellations were held responsible for the spread and intensity of a disease, then this means in the first place that the fate of the individual appeared accessible to the empathy of others; likewise, the individual has to orientate and position himself/herself towards the higher powers. Therefore, it is superfluous and useless to say that we have better knowledge thanks to modern medical science, but we may say - without rejecting modern medicine and natural science - that there are different patterns of interpretation when it comes to those irregularities that are manifest in a disease. These irregularities are either individual and therefore call for personal responsibility, or they are universal if not transcendent. Common to both astrological or supernatural and empirical medical interpretation is that we are looking for a horizon of meaning and a generalizable explanation that will make action possible in the individual case. Individual action is impossible without a sense-framework. If this framework does not exist, action is erratic or absurd or irrational. The rationality underlying both past and modern interpretations of pandemics, epidemics, plagues, or any other mass disease as such is that of searching for the causes.

In the early modern attempts to explain mass infections, the cause was sought outside, i.e., through scrutinizing which external forces may have caused the disorder inside, or whether the individual case was a deviation from the general norm. It is also important to note that the comets or the air or other influences from outside were not only seen as indicators or predictions but also had a causal meaning. The star of Bethlehem was always interpreted as an indication of a world historical event with theological significance. But otherwise, astrology was understood in such a way that one can read from the movement of the stars what will happen on earth, not only as parallel signification but in a cause-effect relationship. A further distinction to think about is the one between facilitating circumstances or conditions that promote illnesses and the direct influence on the illness or even the cause of the illness, which therefore becomes comprehensible.

One question that Ficino pursued, as we saw, was why the stars do not cause the same disease for all people at the same time, when they are the 
universal cause of what happens in this world. For this he has the explanation that the causative power of the spheres must correspond to a readiness in the individual, i.e., a disposition to be ill or a resistance to becoming ill. In this kind of medicine the relationship of the individual has to be put into relation with the universal so that the general power can be causally effective or, on the contrary, its deranging work can be constrained by good behavior on the side of the person. It is crucial that the doctor as well as the patient have to assess the relationship between the sick and the diseasecausing phenomenon, and this creates a transcendental relationship to the overall environment. The higher powers are not cruel or benevolent but demand from the individual a sort of positioning in order to be favorable or unfavorable to the individual.

This necessary relationship between the universal (the divine or astral powers) and the individual is strengthened in Fracastoro's mythical framing of the medical problem. Medicine is a story about sick people, about healers, sinners, and salvation. Mythology and poetry offer this ideal setting of a story that incarnates the failures, the suffering, and the battles of every individual person. Insofar as mythology is the shrouded intervention of the divine, it is also a reminder that every person has to take responsibility in the face of the Creator; and where the religious dimension is not convincing, Syphilus' and the Spaniards' actions remind the reader that personal pride feeds at the expenses of the society. Fernel appears the most secularized among the three authors studied here. And yet, with his theory of occult causation he leaves the door open to admit that every epidemy, in devastating peoples and individuals, remains unspeakable and thus is the embodiment of the human desire for knowledge of the unconcealed truth. When we wonder that Fernel made our ignorance-the occult forces-the methodical key to the cure, we see a parallel in the puzzlement of the general public, and even some officials, today, over the meaning of statistics. Most of the debates over the right actions against the Corona virus circle around the interpretation of data, which are all as uncertain as statistics are, because they are gathered from single cases but extrapolated into probabilities and generic prospects, in which the individual feels overlooked and lost. Disorientation, as we saw, induces to aimless finger-pointing, complottismo, as the Italians say: there is always someone to blame, instead of reflecting upon one's behavior. The face mask that is becoming an everyday attribute of considerate demeanor is emblematic for this mutuality of the self and the surrounding: one takes care of oneself by protecting the others. The most important lesson we can learn from the Renaissance scholars is the aware- 
ness that any mass disease is neither individual nor blindly fatal and not reducible to physiology but the consequence and symptom of how societies and their members interact with each other, with their surrounding nature, and with the transcendent.

\section{BIBLIOGRAPHY}

Agricola, Georg. De peste libri tres. Basel: Froben, 1554.

Beecher, Donald. "Ficino, Theriaca and the Stars." In Marsilio Ficino: His Theology, His Philosophy, His Legacy, edited by Michael J. B. Allen, Valery Rees, and Martin Davies, 24356. Leiden: Brill, 2001.

Beiweis, Susanne. "Saturn und Talisman: Die heterogenen Begriffe der Magie am Beispiel von Marsilio Ficinos 'De vita libri tres.' " Phil. Diss., Wien, 2015.

Beiweis, Susanne K. “ “Naturam Ars Imitatur’: Magical Images within Marsilio Ficino's De Vita Libri Tres.” Verbum - Analecta Neolatina 19, no. 1-2 (2018): 155-80. http://www. verbum-analectaneolatina.hu/en_issue.php?issue=XIX/2018/1-2.

BLum, Paul Richard. "Qualitas occulta.” In Historisches Wörterbuch der Philosophie, 7:1743-47. Basel: Schwabe, 1989.

"Covid-19 und die PhilosophInnen. Eine Übersicht über die mediale Präsenz der Philosophie." Information Philosophie, no. 2 (2020): 16-25.

Fernel, Jean. On the Hidden Causes of Things. Translated by John M. Forrester. [De abditis rerum causis, Lat.-Engl.], edited by John Henry and John M. Forrester. Leiden: Brill, 2005.

FIcino, Marsilio. Consilio contro la pestilenzia, edited by Enrico Musacchio. Bologna: Cappelli, 1983.

Ficino, Marsilio. Three Books on Life, edited by Carol V. Kaske and John R. Clark. Binghamton, NY: Medieval \& Renaissance Texts \& Studies, 1989.

FraCASTORIUS, Hironymus. "De contagionibus et contagiosis morbis et eorum curatione." In Opera omnia, 77r-110v. Venetiis: Iunta, 1584.

Fracastoro, Girolamo. "Syphilis sive de morbo gallico." In Latin poetry. Translated by James Gardner, 1-85. Cambridge, MA: The I Tatti Renaissance Library, Harvard University Press, 2013.

FrischmanN, Bärbel. "Das Virus und die Angst.” Information Philosophie, no. 2 (2020): 8-15.

GinZBurg, Carlo. "Une démocratie grégaire?" En attendant Nadeau (blog), July 11, 2020. https:// www.en-attendant-nadeau.fr/2020/07/12/democratie-gregaire-ginzburg/.

Herrmann, Sabine. Tomaso Rangone: Arzt, Astrologe und Mäzen im Italien der Renaissance. Göttingen: Vandenhoeck \& Ruprecht, 2017.

HiraI, Hiro. "Ficin, Fernel et Fracastor autour du concept de semence: Aspects platoniciens de seminaria." In Girolamo Fracastoro fra medicina, filosofia e scienze della natura: Atti del convegno internazionale di studi in occasione del 450. anniversario della morte, Verona-Padova 9-11 ottobre 2003, edited by Alessandro Pastore and Enrico Peruzzi, 245-60. Firenze: Olschki, 2006. 
Hirai, Hiro. Medical Humanism and Natural Philosophy: Renaissance Debates on Matter, Life and the Soul. Leiden: Brill, 2011.

Hirai, Hiro. "The New Astral Medicine." In A Companion to Astrology in the Renaissance, edited by Brendan Dooley, 267-86. Leiden: Brill, 2014.

Iommi Echeverría, Virginia. "Girolamo Fracastoro y la invención de la sífilis." História, Ciências, Saúde-Manguinhos 17, no. 4 (December 2010): 877-84. DOI: https://doi.org/ 10.1590/S0104-59702010000400002.

Katinis, Teodoro. “A Humanist Confronts the Plague: Ficino's Consilio Contro La Pestilentia." Modern Language Notes 125, no. 1 (2010): 72-83.

Katinis, Teodoro. Medicina e filosofia in Marsilio Ficino: Il Consilio contro la pestilenza. Roma: Edizioni di Storia e Letteratura, 2007.

KoHn, George Childs. Encyclopedia of Plague and Pestilence. $3^{\text {rd }}$ edition. New York: Facts On File, 2008.

Monreal, Ruth. "Eppur lo dice! Come si trasmette la sifilide nel poema didattico di Girolamo Fracastoro." Studi Umanistici Piceni 23 (2003): 179-89.

Müller-Jahncke, Wolf-Dieter. Astrologisch-magische Theorie und Praxis in der Heilkunde der frühen Neuzeit. Sudhoffs Archiv, Beiheft 25. Stuttgart: Steiner, 1985.

Palmer, Ada. "Black Death, COVID, and Why We Keep Telling the Myth of a Renaissance Golden Age and Bad Middle Ages." Ex Urbe. History, Philosophy, Books, Food \& Fandom. Accessed July 14, 2020. https://www.exurbe.com/black-death-covid-and-whywe-keep-telling-the-myth-of-a-renaissance-golden-age-and-bad-middle-ages/.

Pastore, Alessandro, and Enrico Peruzzi (eds.). Girolamo Fracastoro fra medicina, filosofia e scienze della natura: Atti del convegno internazionale di studi in occasione del 450. anniversario della morte, Verona-Padova 9-11 ottobre 2003. Firenze: Olschki, 2006.

\section{EPIDEMIC AND THE INDIVIDUAL: \\ RENAISSANCE UNDERSTANDINGS OF THE PLAGUE IN VIEW OF MODERN EXPERIENCES}

\section{S u m m a ry}

Epidemics are a challenge to individualism. While we tend to think of illnesses in terms of personal suffering and choices, plagues affect communities and societies over long times. Epidemics turn the perspective to the collective, the transcendent, and the external, and fear, therapy and care become universal, rather than individual. These are the lessons we can gather from Renaissance philosophers' theories of epidemics. Marsilio Ficino (1433-1499) gave "Advice against the pestilence" by emphasizing the harmony of body with the environment (air and the planets). Girolamo Fracastoro (1477-1553) produced the first description of "Syphilis," both scientifically and poetically. He invented the name for that contagion. He saw sexual activity as one of the typical behaviors among fellow humans. Care for one's health requires respect for the others; and blaming others (as in 'French disease') is useless. Jean Fernel (1497-1558) called for strictly medical research into epidemics; at the same time, he acknowledged the insufficiency of data; hence the title of his book De abditis rerum causis ("The hidden causes"). Thus, he explained the irrational behavior of populations and some scholars. The task is to live with uncertainty and to contain epidemics by containing the unknown.

Key words: plague; syphilis; Marsilio Ficino; Girolamo Fracastoro; Jean Ferne. 


\section{EPIDEMIA A JEDNOSTKA: \\ RENESANSOWE ROZUMIENIE PLAG \\ Z PERSPEKTYWY NOWOCZESNYCH DOŚWIADCZEŃ}

Streszczenie

Epidemie są wyzwaniem dla indywidualizmu. Chociaż myślimy o chorobach w kategoriach osobistego cierpienia i wyborów, plagi od dawna dotykają wspólnot i społeczności. Epidemie zwracają perspektywę na zbiorowość, transcendencję i to, co zewnętrzne, a strach, terapia i opieka stają się bardziej uniwersalne niż indywidualne. Oto wnioski, które możemy wyciągnąć z teorii epidemii filozofów renesansu. Marsilio Ficino (1433-1499) udzielił „Rady przeciwko zarazie” (Consilio contro la pestilenzia), podkreślając harmonię ciała ze środowiskiem (powietrze i planety). Girolamo Fracastoro (1477-1553) stworzył pierwszy opis kiły (syfilisu) zarówno pod względem naukowym, jak i poetyckim (Syphilis sive de morbo gallico). Wymyślił nazwę dla tej dolegliwości. Postrzegał aktywność seksualną jako jedno z typowych zachowań międzyludzkich. Troska o zdrowie wymaga szacunku dla innych, a obwinianie innych (jak w przypadku ,choroby francuskiej”) jest bezużyteczne. Jean Fernel (1497-1558) wezwał do ściśle medycznych badań epidemii, jednocześnie przyznając, że dane są niewystarczające, stąd tytuł jego książki De abditis rerum causis („Ukryte przyczyny”). W ten sposób wyjaśnił irracjonalne zachowanie populacji i niektórych uczonych. Zadaniem jest przeżycie w niepewności i powstrzymanie epidemii poprzez powstrzymanie nieznanego.

Słowa kluczowe: plaga; syfilis; Marsilio Ficino; Girolamo Fracastoro; Jean Ferne. 